\title{
Araștırma Makalesi \\ Farklı Tozlayıcıların Precoce de Tyrinthe Kayısı Çeşidinin Bazı Meyve Özellikleri Üzerine Etkisi
}

ÖZ

\author{
Mehmet YAMAN ${ }^{*}$, Aydın UZUN ${ }^{1}$
}

Türkiye, çok sayıda Prunus türünün anavatanı konumunda olarak bu alanda güçlü bir potansiyele sahiptir. Prunus türleri ekonomik öneme sahip olan önemli türleri meyve türlerini oluşturmaktadır. Bu meyveler arasında yer alan kayısıda yapılan bu çalışma 2019 ve 2020 yıllarında Malatya ilinde yürütülmüştür ve Tyrinthe kayısı çeşidinde melezleme ıslahı ile meyve tutumu ve bazı meyve özellikleri üzerine baba ebeveyn olarak kullanılan Hasanbey, Aprikoz, Hasanbey çeşitlerinin etkisi araştırılmıştır. Çalışma sonuçlarına göre 2019 ve 2020 yıllarında en iyi meyve tutumu Tyrinthe $x$ Hasanbey kombinasyonlarında sırasıyla \%15.8 ve \%18.92 olarak gerçekleşmiştir. Meyve ağırlığ 1 ve meyve eni değerlerinde her iki yılda da Hacıhaliloğlu çeşidinin baba olarak kullanıldığı kombinasyon diğer kombinasyonlara göre daha iyi sonuçlar meydana getirmiştir. Genel olarak baba olarak kullanılan çeşitlerin meyve boyuna olumlu etkisi az olurken, SÇKM değerlerini arttırıcı yönde sonuçlar meydana gelmiştir. Elde edilen sonuçların özellikle kayısı 1slahı çalışmalarında fikir beyan etmesi açısından kullanılması ıslahçılar için yarar sağlayabilir.

Anahtar Kelimeler: Kayısı, Precoce de Tyrinthe, uyuşmazlık, meyve tutumu, Malatya.

\section{Effect of Different Pollinators on Fruit Set and Some Fruit Characteristics in Precoce de Tyrinthe Apricot Variety}

\begin{abstract}
Turkey has a strong potential in this area, being the homeland of many Prunus species. Prunus species constitute important fruit species of economic importance. This study on apricot, which is among these fruit species, was carried out in Malatya in 2019 and 2020 years, and it was aimed to determine the effect of Hasanbey, Aprikoz, Hasanbey varieties used as father parent on fruit set and some fruit characteristics with hybridization breeding in Tyrinthe apricot variety. According to the results of the study, the highest fruit set occurred in Tyrinthe x Hasanbey combinations in 2019 and 2020 , and it was $15.8 \%$ and $18.92 \%$ respectively by years. The combination in which Hacihaliloğlu variety was used as paternal parent yielded better results in both years in terms of fruit weight and fruit width than other combinations. In general, the positive effect of the varieties used as paternal parents on fruit size was less, but there were results in increasing the total soluble solids(TSS) values. The in flesh/stone ratios occurred differences depending on pollinator type in 2020. Current study results, it may be beneficial especially in apricot breeding studies.
\end{abstract}

Keywords: Apricot, Precoce de Tyrinthe, incompatibility, fruit set, Malatya.

ORCID ID (Yazar sirasına göre)

0000-0002-2899-2238, 0000-0001-9496-0640

\footnotetext{
Yayın Kuruluna Geliş Tarihi: 05.04.2021

Kabul Tarihi: 21.05.2021

${ }^{1}$ Erciyes Üniversitesi Ziraat Fakültesi Bahçe Bitkileri Bölümü, Kayseri, Türkiye

*E-posta: mhmt.-07@ hotmail.com
} 


\section{Farklı Tozlayıcıların Precoce de Tyrinthe Kayısı Çeşidinin Bazı Meyve Özellikleri Üzerine Etkisi}

\section{Giriş}

Ülkemiz kayısı, kiraz, erik, şeftali, badem gibi Prunus türlerinde önemli ticari çeşitlere sahip olmasının yanında üretim miktarları bakımından da dünyada önemli bir yerdedir (Ercisli, 2004; Uzun ve ark., 2018). Bu türler dişında bulunduğumuz coğrafyanın bize sağlamış olduğu farklı ekolojik koşullar yine farklı yabani Prunus türlerinin de ülkemizde binlerce y1ldır varlığını sürdürmesine olanak sağlamıştır.

Önemli Prunus türleri içerisinde yer alan kayısıda Türkiye üretimi 846606 ton ile yaklaşık 4 milyon ton olan dünya üretiminde ilk sıradadır (FAO 2019). Türkiye'de kayısı üretiminin yüksek olma sebepleri arasında; Türkiye'nin kayısının anavatan bölgeleri arasında yer alması ve ülke geneline kayısının çok iyi uyum sağlaması örnek olarak verilebilir (Yaman ve Uzun, 2020). Bu büyük ölçekli üretime rağmen ülke genelinde kayısıda özellikle meyve tutumundan kaynaklanan ve verimi etkileyen birtakım olumsuzluklar gözükmektedir. Bu sorunlar arasında en sık karşılaşılanı ilkbahar geç donları ve kayısıda görülen kendine uyuşmazlıktan kaynaklı kısmı ya da hiç ürün alınamamasıdır. Meyve yetiştiriciliğinin asıl amacı ekonomik olarak yüksek verim elde etmektir ve kendine uyuşmazlığın görüldüğü meyve türlerinde başarılı bir tozlanma için mutlak tozlayıcı kullanmayı gerektirmektedir. (Ortege ve ark., 2004).

Bitkilerde uyuşmazlık mekanizmasının S allel genleriyle ilişkili olduğu yapılan çalışmalarda ortaya konulmuştur (Korkmaz ve ark., 2015; Y1lmaz ve ark., 2016). Bu s allel genleri sadece ürün alma noktasında değil aynı zamanda tür içi ve türler arası 1slah çalışmalarında genetik çeşitlilik oluşturma noktasında yarar sağlamaktadır (Gómez ve ark., 2019, Yaman ve Uzun, 2020). Buna ek olarak kullanılan farklı tozlayıcı kullanmanın meyvede kalite özellikleri olarak kabul gören irilik, şekil, SÇKM gibi çoğu özelliğe etki ettiği bilinmektedir. Kayısının yanı sıra Mandarinde (Yıldız ve Kaplankıran 2017) kiraz da (Curtlık ve Beyhan, 2012), bademde (Uzun ve Yaman, 2021) farklı tozlayıc1 kullanımının meyve tutumu ve meyve kalitesine olan etkileri yapilan farklı çalışmalarda belirlenmiştir.
Yapılan bu çalışmada erkenci kayısı çeşitleri arasında üretimde önemli bir yeri olan Tyrinthe kayısı çeşidinde Hacıhaliloğlu ve Aprikoz kayısı çeşitleri ile melezleme 1slahı yöntemiyle meyve tutumu ve bazı meyve özelliklerine olan etkilerinin araştırılması amaçlanmıştır.

\section{Materyal ve Yöntem Materyal}

$\mathrm{Bu}$ çalışma Malatya Kayısı Araştırma Enstitüsü bünyesinde bulunan kayısı koleksiyon bahçesinde yürütülmüştür. Çalışmada $P$. Tyrinthe kayısı çeşidi ana ebeveyn olarak kullanılmıştır. Hacıhaliloğlu, Hasanbey ve Aprikoz kayısı çeşitleri baba ebeveyn olarak kullanılmıştır. Çalışma bahçesi 1995 yılında kurulmuştur. Toprak yapısı itibariyle tınlı-killi' dir. Ağaçlar 25 yaşl1 olup araştırma yerinin çiçeklenme, tozlanma, döllenme ve meyve gelişim dönemlerine ait meteorolojik veriler tablo 1 'de yer almaktadır.

\section{Metot}

Baba ebeveynlere (Hacihaliloğlu, Hasanbey ve Aprikoz) ait çiçek tozları balon aşamasına gelmiş henüz açmamış çiçek tomurcuklarından temin edilmiştir. Bir sulu boya firçası yardımıyla emaskulasyonu yapılmış çiçeklere polenler sürülmüş ve melezleme işlemi gerçekleştirilmiştir. Meyve tutum oranları; tutan meyve sayısının toplam melezlenen çiçek sayısına bölünmesi ve elde edilen sonucun 100 ile çarpılması sonucunda belirlenmiştir.

Pomolojik özelliklerin belirlenmesinde hasat olumuna gelen kayısı meyveleri toplanarak, her kombinasyondan 10 adet meyvede; ağırlığı (gr), meyve eni $(\mathrm{mm})$, meyve boyu(mm), kabuk rengi, et rengi, SÇKM (\%), et/çekirdek oranı, $\mathrm{pH}$, asit (\%), çekirdek eni(mm), çekirdek boyu $(\mathrm{mm})$, çekirdek ağırlı̆̆ 1 gr) gibi parametrelerde gerekli ölçümler yapılmıştır (Özkarakaş ve ark., 2008; Son 2018).

Verilerin analizinde SPSS (Statistical Package for the Social Sciences) 15.0 program1 kullanılmıştır. Sonuçlar arasındaki farklılığın değerlendirilmesinde "Duncan" çoklu karşılaştırma testi kullanılmıştır. Kombinasyonlara ait değerler ortalama \pm standart Sapma (SS) şeklinde sunulmuştur. Tüm 


\section{Farklı Tozlayıcıların Precoce de Tyrinthe Kayısı Çeşidinin Bazı Meyve Özellikleri Üzerine Etkisi}

istatistiksel analizler $p<0,05$ ve $p<0,01$ önemlilik düzeyinde gerçekleştirilmiştir.

\section{Bulgular ve Tartışma}

Çalışmanın yürütüldüğü 2019 yılı sonuçlarında tutan meyve sayıları incelendiğinde en fazla tutum P. Tyrinthe $\times$ Hasanbey kombinasyonundan 79 meyve olarak, meyve tutum oranı ise yine bu kombinasyonda \%15.8 olarak gerçekleşmiştir (Tablo 2). En düşük tutum ise 11 adet meyve ve $\% 2.2$ oranla P. Tyrinthe $\times$ Hacihaliloğlu kombinasyonundan elde edilmiştir. 2020 yılı meyve tutum oranlarında tutan meyve sayısı bakımından en yükssek değer 35 meyve ile $P$. Tyrinthe $\times$ Hasanbey kombinasyonundan sağlanmıştır. En düşük meyve tutumu ise 11 meyve ile $\mathrm{P}$. Tyrinthe $\times$ Aprikoz kombinasyonundan elde edilmiştir. En yüksek meyve tutma yüzdesi \%18.92 ile $\mathrm{P}$. Tyrinthe $\times$ Hasanbey kombinasyonundan elde edilmiştir (Tablo 3). Çalışmanın her iki yılında da Hasanbey kayısı çeşidinin baba ebeveyn olarak kullanıldığı kombinasyonlarda tutan meyve sayısı ve meyve tutma yüzdesinde en iyi sonuçlar elde edilmiştir. Jie ve ark. (2005), tarafindan kayısıda meyve tutumu üzerine yapmış oldukları çalışmada, kayısıda kendilemede Badan, Hongyu, Hongfeng, ×inshiji, Honghebao çeşitlerinde \%0-0.6 arasında, Katy çeşidinde ise \%17.6 düzeyinde meyve tutumu belirlemişlerdir. Karş1liklı melezlemede ise \%0 ile \%39.4 arasinda meyve tutumu elde etmişlerdir. Bircan ve ark., (2013) Aurora kayısı çeşidinde farklı baba ebeveynler kullanarak yapmış oldukları çalışmada meyve tutma değerlerinin \%4.42 ile \%14.60 arasında değişim gösterdiğini belirlemişlerdir. Canino kayısı çeşidinde tür içi melezlemeler ile farklı tozlayicılarin meyve tutum ve kalitesine etkisinin belirlenmesi amaciyla yapılan çalışma da tozlayıcı çeşide bağlı olarak meyve tutum oranlarının \%21,7 ile $\% 18,04$ arasında değişim gösterdiği belirlenmiştir (Taha and Sheriff, 2015). Mevcut çalışmada elde edilen değerler literatürdeki değerler ile benzer niteliğe sahiptir.

Tablo 1 . Çalışmanın yapıldığı lokasyona ait meteorolojik veriler

\begin{tabular}{|clccccc|}
\hline Yıl & Ay & $\begin{array}{c}\text { Maksimum } \\
\text { sıcaklık }\left({ }^{\circ} \mathbf{C}\right)\end{array}$ & $\begin{array}{c}\text { Minimum } \\
\text { sıcaklık }\left({ }^{\circ} \mathbf{C}\right)\end{array}$ & $\begin{array}{c}\text { Ortalama nispi } \\
\text { nem }(\boldsymbol{\%})\end{array}$ & $\begin{array}{c}\text { Ortalama } \\
\text { rüzgâr } \\
\text { hızı(m/s) }\end{array}$ & $\begin{array}{c}\text { Ortalama } \\
\text { sıcaklık }\left({ }^{\circ} \mathbf{C}\right)\end{array}$ \\
\hline \multirow{2}{*}{$\mathbf{2 0 1 9}$} & Mart & 17.9 & -3.8 & 86.2 & 1.7 & 7.3 \\
\cline { 2 - 7 } & Nisan & 23.8 & 0.8 & 82.1 & 1.6 & 10.5 \\
\cline { 2 - 7 } & Mayıs & 34.3 & 5.4 & 45.6 & 1.9 & 19.5 \\
\cline { 2 - 7 } & Haziran & 37.1 & 12.5 & 42.9 & 1.8 & 24.4 \\
\hline \multirow{2}{*}{$\mathbf{2 0 2 0}$} & Mart & 20.7 & -1.2 & 69.6 & 1.5 & 8.8 \\
\cline { 2 - 7 } & Nisan & 24.5 & 0.9 & 57.2 & 1.7 & 12.4 \\
\cline { 2 - 7 } & Mayis & 33.5 & 4.9 & 49.0 & 2.0 & 18.0 \\
\cline { 2 - 7 } & Haziran & 33.4 & 9.1 & 41.3 & 1.8 & 22.6 \\
\hline
\end{tabular}

Tablo 2. 2019 y1lı melezlemelerine ait veriler

\begin{tabular}{|lccc|}
\hline Kombinasyon & $\begin{array}{c}\text { Melezlenen } \\
\text { çiçek sayısı (adet) }\end{array}$ & $\begin{array}{c}\text { Tutan Meyve } \\
\text { Sayısı (adet) }\end{array}$ & $\begin{array}{c}\text { Meyve tutum } \\
\text { oranı (\%) }\end{array}$ \\
\hline P. Tyrinthe $\times$ Hacihaliloğlu & 500 & 11 & 2.2 \\
\hline P. Tyrinthe $\times$ Hasanbey & 500 & 79 & 15.8 \\
\hline P. Tyrinthe $\times$ Aprikoz & 500 & 27 & 5.4 \\
\hline
\end{tabular}




\section{Farkı Tozlayıııların Precoce de Tyrinthe Kayısı Çeşidinin Bazı Meyve Özellikleri Üzerine Etkisi}

Tablo 3. 2020 y1lı melezlemelerine ait veriler

\begin{tabular}{|lccc|}
\hline Kombinasyon & $\begin{array}{c}\text { Melezlenen çiçek } \\
\text { sayısı (adet) }\end{array}$ & $\begin{array}{c}\text { Tutan Meyve } \\
\text { Sayısı (adet) }\end{array}$ & $\begin{array}{c}\text { Meyve tutum } \\
\text { oranı (\%) }\end{array}$ \\
\hline P. Tyrinthe $\times$ Hacihaliloğlu & 292 & 12 & 4.11 \\
\hline P. Tyrinthe $\times$ Hasanbey & 185 & 35 & 18.92 \\
\hline P. Tyrinthe $\times$ Aprikoz & 256 & 11 & 4.30 \\
\hline
\end{tabular}

Araştırmanın 2019 yılında meyve ağırlığında en yüksek değer $37.13 \mathrm{~g}$ ile $\mathrm{P}$. Tyrinthe $\times$ Hacıhaliloğlu kombinasyonundan elde edilirken, en düşük meyve ağırlığ $32.25 \mathrm{~g}$ ile P. Tyrinthe $\times$ Hasanbey kombinasyonundan sağlanmıștır. $\mathrm{Bu}$ verilere göre Hacihaliloğlu ve Aprioz melezleme kombinasyonları, P. Tyrinthe çeşidinin açıkta tozlanan meyvelerine göre daha ağır meyveleri meydana getirmiştir. Çalışmanın bu yılında ortalama meyve ağırlı̆̆ $34.11 \mathrm{~g}$, minumum meyve ağırlığ $21.82 \mathrm{~g}$, maksimum meyve ağırlığ $44.07 \mathrm{~g}$ olarak belirlenmiştir. 2020 yılı sonuçlarında ise meyve ağırlığında 2019 y1lına göre ciddi bir artış meydana gelmiştir. Buna bağlı olarak en düşük meyve ağırlığı $70.55 \mathrm{~g}$ ile P. Tyrinthe $\times$ Hasanbey kombinasyonundan elde edilirken, en yüksek meyve ağırlığ $79.64 \mathrm{~g}$ ile $P$. Tyrinthe $\times$ Hacihaliloğlu melezlemelerinden elde edilmiştir. Y1l ortalaması ise $73.79 \mathrm{~g}$ olarak ortaya çıkmıştır. Pınar ve ark., 2017 melezleme 1slahı sonucunda elde edilen kayısı genotiplerinde meyve ağırlığ değerlerinin 25.52 $\mathrm{g}$ ile $65.10 \mathrm{~g}$ arasında değiştiğini ve genel olarak elde edilen melez bireylerin ana ve baba bireylerden meyve ağırlığı yönünden üstün olduğunu belirlemişlerdir (Pınar ve ark., 2017). Hacıhaliloğlu' $x$ 'Boccucia kayısı melez kombinasyonundan elde edilen hibrid bireylerde meyve ağırlığı bakımından minimum değer $14.13 \mathrm{gr}$, maksimum değer 46.15 gr ve ortalama değer 26.07 gr olarak belirlenmiştir (Bilgin ve ark., 2020). Mevcut çalışmada elde edilen sonuçlar literatürdeki çalışmaylar ile kısmi benzerlik göstermekle birlikte, görülen farklılıkların melezleme kombinasyonlarının farklı olması, incelemelerin tozlanma sonrasındaki meyvelerde incelenmesi ve tozlanmada kullanılan ağaçların meyve yükünden kaynaklandığı söylenebilir.

Tablo 4. 2019 ve 2020 yılında tozlayıcılara bağl1 meyve ağırlığ değerleri

\begin{tabular}{|lcccc|}
\hline & \multicolumn{2}{c}{$\mathbf{2 0 1 9}$} & \multicolumn{2}{c|}{$\mathbf{2 0 2 0}$} \\
\hline Kombinasyon & $\begin{array}{c}\text { Meyve } \\
\text { Ağırlığ } \\
(\mathbf{g})\end{array}$ & Min.-Maks. & $\begin{array}{c}\text { Meyve } \\
\text { Ăgırlı̆̆ } \\
(\mathbf{g})\end{array}$ & Min.-Maks. \\
\hline P. Tyrinthe & $32.63 \pm 4.58^{\mathrm{b}}$ & $25.36-40.28$ & $71.92 \pm 6.41^{\mathrm{b}}$ & $62.31-80.31$ \\
\hline P. Tyrinthe $\times$ Hacihaliloğlu & $37.13 \pm 6.42^{\mathrm{a}}$ & $21.82-44.07$ & $79.64 \pm 4.74^{\mathrm{a}}$ & $73.51-89.07$ \\
\hline P. Tyrinthe $\times$ Hasanbey & $32.25 \pm 3.42^{\mathrm{b}}$ & $26.71-38.44$ & $70.55 \pm 5.19^{\mathrm{b}}$ & $62.15-19.95$ \\
\hline P. Tyrinthe $\times$ Aprikoz & $35.79 \pm 5.72^{\text {ba }}$ & $24.18-42.19$ & $75.01 \pm 8.57^{\mathrm{ab}}$ & $58.36-82.63$ \\
\hline Ortalama & $\mathbf{3 4 . 1 1} \pm \mathbf{5 . 2 5}$ & $\mathbf{2 1 . 8 2 - 4 4 . 0 7}$ & $\mathbf{7 3 . 7 9} \pm 6.98$ & $\mathbf{5 8 . 3 6 - 8 9 . 0 7}$ \\
\hline
\end{tabular}

*Farklı küçük harfler ait olduğu yılın sütunları arasında istatistiksel olarak önemli farkları göstermektedir $(p<0,05)$.

2019 yılında en yüksek meyve boyu $43.83 \mathrm{~mm}$ ile P. Thyrinte $x$ Hacihaliloğlu kombinasyonundan elde edilirken, en düşük meyve boyu $41.73 \mathrm{~mm}$ ile $P$. Thyrinte $\mathrm{x}$ Hasanbey kombinasyonundan sağlanmıştır. $\mathrm{Bu}$ verilere göre Hacihaliloğlu melezleme kombinasyonu P. Thyrinte çeşidinin açıkta tozlanan meyvelerine göre meyve eni bakımından daha büyük meyveler meydana getirmiştir. Çalışmanın 2019 yılında ortalama meyve eni $43,11 \mathrm{~mm}$, minumum meyve eni $36.93 \mathrm{~mm}$, maksimum meyve eni $49.63 \mathrm{~mm}$ olarak tespit edilmiştir. 2020 y1lı verilerinde sonuçlar istatistiki olarak önemli olmamakla 


\section{Farklı Tozlayıcıların Precoce de Tyrinthe Kayısı Çeşidinin Bazı Meyve Özellikleri Üzerine Etkisi}

beraber, meyve ağırlığındaki artışa bağlı olarak meyve boyu değerlerindede artış görülmekte olup, en düşük değer P. Thyrinte $\mathrm{x}$ Hasanbey melezleme kombinasyonundan $51.24 \mathrm{~mm}$ olarak elde edilirken, en yüksek değer $53.02 \mathrm{~mm}$ ile P. Thyrinte $\mathrm{x}$ Hacihaliloğlu kombinasyonundan elde edilmiştir. Y1l ortalamas $51.88 \mathrm{~mm}$ olarak, minumum değer $45.98 \mathrm{~mm}$ ve maksimum değer $56.93 \mathrm{~mm}$ olarak bulunmuştur. Aydın ekolojik koşullarında Ninfa ve Tyrinthe kayısı çeşitlerinde meyve boyu değerleri sirasıyla 33.23 ile $37.77 \mathrm{~mm}$ arasında belirlenmiștir
(Karakum, 2016). Mevcut çalışmada elde edilen sonuçlar literatürdeki bu çalışma ile meyve boyu yönünden farklılıklara sahiptir. Ortaya çıkan bu farklılığın sebebi ekolojik koşulların farklı olmasından kaynaklanabilir. Başka bir çalışmada ise Pınar ve ark., 2017 kayısı melezlerinde meyve boyu değerlerinin 34.58 $($ Fer $\times$ Col-12) ile 48.50 (AY $\times$ P-5) $\mathrm{mm}$ arasinda değişim gösterdiğini rapor etmişlerdir. Mevcut çalışma ve literatürdeki bu çalışma meyve boyu yönünden benzer özellikler taşımaktadır.

Tablo 5. 2019 ve 2020 yılında tozlayıcılara bağlı meyve boyu değerleri

\begin{tabular}{|lcccc|}
\hline Kombinasyon & \multicolumn{2}{c}{$\mathbf{2 0 1 9}$} & \multicolumn{2}{c|}{$\mathbf{2 0 2 0}$} \\
& $\begin{array}{c}\text { Meyve Boyu } \\
(\mathbf{m m})\end{array}$ & Min.-Maks. & $\begin{array}{c}\text { Meyve Boyu } \\
(\mathbf{m m})\end{array}$ & Min.-Maks. \\
\hline P. Tyrinthe & $43.70 \pm 3.48^{\mathrm{a}}$ & $36.93-49.63$ & $52.02 \pm 4.11$ & $45.98-56.93$ \\
\hline P. Tyrinthe $\times$ Hacihaliloğlu & $43.83 \pm 2.55^{\text {a }}$ & $37.35-46.58$ & $53.02 \pm 2.30$ & $48.73-56.12$ \\
\hline P. Tyrinthe $\times$ Hasanbey & $41.73 \pm 1.84^{\mathrm{b}}$ & $37.43-44.55$ & $51.24 \pm 1.86$ & $48.35-54.92$ \\
\hline P. Tyrinthe $\times$ Aprikoz & $43.52 \pm 1.83^{\text {a }}$ & $40.02-47.47$ & $51.68 \pm 1.55$ & $49.67-54.67$ \\
\hline Ortalama & $\mathbf{4 3 . 1 1} \pm \mathbf{2 . 6 1}$ & $\mathbf{3 6 . 9 3 - 4 9 . 6 3}$ & $\mathbf{5 1 . 8 8} \pm \mathbf{2 . 5 0}$ & $\mathbf{4 5 . 9 8 - 5 6 . 9 3}$ \\
\hline
\end{tabular}

*Farklı küçük harfler ait olduğu yılın sütunları arasında istatistiksel olarak önemli farkları göstermektedir $(p<0,05)$.

Tablo 6. 2019 ve 2020 yılında tozlayıcılara bağlı meyve eni değerleri

\begin{tabular}{|lcccc|}
\hline & \multicolumn{2}{c}{$\mathbf{2 0 1 9}$} & \multicolumn{2}{c|}{2020} \\
\hline Kombinasyon & $\begin{array}{c}\text { Meyve Eni } \\
(\mathbf{m m})\end{array}$ & Min.-Maks. & $\begin{array}{c}\text { Meyve Eni } \\
(\mathbf{m m})\end{array}$ & Min.-Maks. \\
\hline P. Thyrinte & $34.34 \pm 4.80^{\mathrm{b}}$ & $22.71-42.37$ & $45.36 \pm 3.08^{\mathrm{b}}$ & $40.19-50.36$ \\
\hline P. Thyrinte x Hacihaliloğlu & $37.26 \pm 3.15^{\text {a }}$ & $29.80-40.22$ & $49.04 \pm 1.46^{\mathrm{a}}$ & $47.16-51.09$ \\
\hline P. Thyrinte x Hasanbey & $36.22 \pm 1.69^{\text {ba }}$ & $32.26-38.93$ & $47.74 \pm 2.13^{\mathrm{a}}$ & $44.42-51.48$ \\
\hline P. Thyrinte x Aprikoz & $36.94 \pm 2.85^{\mathrm{a}}$ & $31.58-40.35$ & $48.25 \pm 2.16^{\mathrm{a}}$ & $44.10-50.40$ \\
\hline Ortalama & $\mathbf{3 6 . 0 5} \pm \mathbf{3 . 4 6}$ & $\mathbf{2 7 . 7 1 - 4 2 . 3 7}$ & $\mathbf{4 7 . 6 9} \pm \mathbf{2 . 4 9}$ & $\mathbf{4 0 . 1 9 - 5 1 . 4 8}$ \\
\hline
\end{tabular}

*Farklı küçük harfler ait olduğu yılın sütunları arasında istatistiksel olarak önemli farkları göstermektedir $(p<0,05)$.

2019 y1lında kombinasyonlara ait meyve eni değerleri P. Thyrinte çeşidinin açıkta tozlanan normal meyvelerine göre daha yüksektir. Sonuçlara göre en yüksek meyve eni değeri $37.26 \mathrm{~mm}$ ile P. Thyrinte x Hacihaliloğlu kombinasyonundan, en düşük meyve eni 36.22 $\mathrm{mm}$ ile $\mathrm{P}$. Thyrinte $\mathrm{x}$ Hasanbey kombinasyonundan elde edilmiştir. Meyve eni ortalamas1 $36.05 \mathrm{~mm}$ olarak, minimum meyve eni $27.71 \mathrm{~mm}$, maksimum meyve eni $42.37 \mathrm{~mm}$ şeklinde gerçekleşmiştir. 2020 yılı sonuçlarında kombinasyonlar arasında meyve eni değerlerinde en düşük değeri $47.74 \mathrm{~mm}$ ile P. Thyrinte x Hasanbey melezlemeleri, en yüksek değeri ise $P$. Thyrinte $x$ Hacihaliloğlu melezlemeleri $(49.04 \mathrm{~mm})$ vermiştir. Y1l ortalaması $47.69 \mathrm{~mm}$ olarak gerçekleşmiştir. Hacıhaliloğlu çeşidinde monilya hastalığına dayanımın arttırılmasi amaciyla yapilan melezleme ıslahı çalışmasında elde edilen melez popülasyonda meyve eni değerlerinin melezlerin büyük çoğunluğununda (\%71.07) 31.63-39.34 


\section{Farklı Tozlayıcıların Precoce de Tyrinthe Kayısı Çeşidinin Bazı Meyve Özellikleri Üzerine Etkisi}

$\mathrm{mm}$ arasında değișim gösterdiği belirlenmiștir (Acarsoy Bilgin ve ark., 2016). Alata Yıldiz1, Çağataybey, Çağrıbey, Feriana, P. de Colomer ve Priana kayısı çeşitlerinde yapılan pomolojik analizler sonucunda meyve eni değerlerinin
32.09 (Feriana) mm ile 39.89 (Alata Yıldız1) mm arasında değişim gösterdiği belirlenmiştir (Pınar ve ark., 2017). Mevcut çalıșma meyve eni bakımından literatürdeki her iki çalışmaylada benzer özellik taşımaktadır.

Tablo 7. 2019 ve 2020 yılında tozlayıcılara bağlı SÇKM değerleri

\begin{tabular}{|lcccc|}
\hline & \multicolumn{2}{c}{$\mathbf{2 0 1 9}$} & \multicolumn{2}{c|}{$\mathbf{2 0 2 0}$} \\
\hline Kombinasyon & SÇKM(\%) & Min.-Maks. & SÇKM(\%) & Min.-Maks. \\
\hline P. Tyrinthe & $9.83 \pm 0.30^{\mathrm{b}}$ & $9.50-10.10$ & $9.45 \pm 0.60^{\mathrm{b}}$ & $8.40-10.70$ \\
\hline P. Tyrinthe $\times$ Hacihaliloğlu & $10.26 \pm 0.20^{\text {ba }}$ & $10.10-10.50$ & $10.39 \pm 0.52^{\mathrm{a}}$ & $9.40-11.20$ \\
\hline P. Tyrinthe $\times$ Hasanbey & $10.70 \pm 0.20^{\mathrm{a}}$ & $10.50-10.90$ & $10.70 \pm 0.58^{\mathrm{a}}$ & $9.40-11.80$ \\
\hline P. Tyrinthe $\times$ Aprikoz & $10.66 \pm 0.25^{\mathrm{a}}$ & $10.40-10.90$ & $10.66 \pm 0.26^{\mathrm{a}}$ & $10.10-11.10$ \\
\hline Ortalama & $\mathbf{1 0 . 3 6} \pm \mathbf{0 . 4 2}$ & $\mathbf{9 . 5 0 - 1 0 . 9 0}$ & $\mathbf{1 0 . 3 9} \pm \mathbf{0 . 6 9}$ & $\mathbf{8 . 4 0 - 1 1 . 8 0}$ \\
\hline
\end{tabular}

*Farklı küçük harfler ait olduğu yılın sütunları arasında istatistiksel olarak önemli farkları göstermektedir $(p<0,05)$.

Çalışmanın her iki yılında da kombinasyonlarda baba olarak kullanılan kayısı çeşitlerinin sonuçları P. Tyrinthe çeşidinin açıta tozlanan meyvelerine göre daha yüksek SÇKM değerlerine sahip olmuştur. 2019 yılında En yüksek SÇKM değeri 10.70 ile P. Tyrinthe $\times$ Hasanbey kombinasyonundan sağlanmıştır. $\mathrm{Bu}$ yıla ait SÇKM ortalaması 10.36, Minimum SÇKM değeri 9.50, maksimum SÇKM değeri 10.90 olarak belirlenmiştir. 2020 y1lı verilerinde ise bütün kombinasyonlarda SÇKM değerleri 2019 yılına göre artış göstermiştir. Buna bağlı olarak en düşük değer \%10.39 ile P. Tyrinthe $\times$ Hacihaliloğlu melezlemesinden, en yüksek değer ise $\% 10.70$ ile $P$. Tyrinthe $\times$ Hasanbey kombinasyonunda belirlenmiștir. San Castrase, Nugget, Boccuccia ve Ivonne Liverani çeşitleri baba ebeveyn olarak, Hacrhaliloğlu çeşidinin ana ebeveyn olarak gerçekleştirildiği bir çalışmada ve elde edilen 345 hibrit bireyde SÇKM değeri \%9.40- 22.60 arasında değişim göstermiştir (Bilgin ve ark., 2016).

\section{Kaynaklar}

Bilgin N, A, Evrenosoğlu Y, Yılmaz K. U, Yiğit T, Kokargül R, Gökalp K, Misırlı A. (2016) Melez Kayıs1 Populasyonunun Meyve Kalite Özellikleri ile İlgili Genel Değerlendirme. Ege Üniv. Ziraat Fak. Derg., 53(1): 25-34.
Malatyada farklı çeşit ve genotiplerde SÇKM değerinin \%12.79-27.18 arasında değiştiği belirlenmiştir (Yanar, 2016). Bir diğer çalışmada 'Beliana', 'Feriana', 'Ninfa' ve 'Precoce de Tyrinthe' kayıs (Prunus armeniaca L.) çeşitlerinin fenolojik ve pomolojik özelliklerinin belirlenmesi amacıyla SÇKM değerleri 11.06 ile 14.06 arasında değişim göstermişstir (Son ve Bahar, 2018).

Sonuç olarak, 2019 ve 2020 yılllarında elde edilen sonuçlara göre en yüksek meyve tutumu P. Tyrinthe $\times$ Hasanbey kombinasyonu sağlanmıştır. Kombinasyonlarda her iki yılda da meyve ağırlığı ve meyve boyu bakımından P. Tyrinthe $\times$ Hacihaliloğlu, meyve eni bakımından P. Tyrinthe $\times$ Hacihaliloğlu ve P. Tyrinthe $\times$ Aprikoz kombinasyonları öne çıkmıştır. Elde edilen sonuçların özellikle kayısıda melezleme 1slahı çalışmalarında kullanılması araştırmacılar için yol gösterici nitelikte olacağı öngörülmektedir.

Bilgin, N. A., Evrenosoğlu, Y., Misırlı, A., Kokargül, R. (2020) Analysis of Fruit Properties of'Hacihaliloğlu' $\times$ 'Boccucia'Hybrid Population. Erwerbs-Obstbau, 1-9.

Bircan, M., Paydaş, S. (2013) Aurora Kayısı Çeşidinin Döllenme Biyolojisi Üzerin Araştırmalar, Alatarım, 12(2): 10-19. 


\section{Farklı Tozlayıcıların Precoce de Tyrinthe Kayısı Çeşidinin Bazı Meyve Özellikleri Üzerine Etkisi}

Cirtlik, B. K., Beyhan, N. (2012) Amasya yöresinde yetiştirilen bazı önemli yerel kiraz çeşitlerinin Ziraat 900 için tozlayıcı olarak kullanılabilirliklerinin araştırılması. Anadolu Tar. Bil. Dergisi, 27(2): 64-69.

Ercisli, S. (2004) A short review of the fruit germplasm resources of Turkey. Genet Resour Crop Ev., 51: 419-435.

Gómez M. E., Dicenta, F., Batlle, I., Romero A., Ortega, E. (2019) Cross-incompatibility in the cultivated almond (Prunus dulcis): Updating, revision and correction, Scientia

Horticulturae 245:21822. February 2019.

Jie, Q., Shupeng, G., Jixiang, Z., Manru, G., Huairui, S. (2005) Identification of selfincompatibility genotypes of apricot (Prunus armeniaca L.) by S-allelespecific PCR analysis. Biotechnology Letters, 27: 1205-1209.

Karakurum, F. (2016) Örtüaltında yetiştirilen erik ve kayısı çeşitlerinde hidrojen siyanamid (H2CN2) uygulamasinın erkencilik ve verim üzerine etkileri (Master's thesis, Adnan Menderes Üniversitesi, Fen Bilimleri Enstitüsü).

Korkmaz, Ş., Bekir, A. K., Sakar, E., Turanoğlu, I., Söylemez, S. (2015) Meyve ağaçlarında uyuşmazlık ve mekanizması. Harran Tarım ve Gida Bilimleri Dergisi, 19(3), 180-186.

Özkarakaş, İ., Ercan, N., Gürnil, K., Tokmak, s., Küçük, E. (2008) Bazı önemli kayısı (Prunus armeniaca L.) çeşitlerinin Ege bölgesi koşullarında değerlendirilmesi. Anadolu Ege Tarımsal Araştırma Enstitüsü Dergisi, 18 (1), 30-48.

Pınar, H., Ercisli, S., Bircan, M., Unlu, M., Uzun, A., Yilmaz, K. U., Yaman, M. (2017) Morphological, Molecular, and Self-(In) Compatibility Characteristics of New Promising Apricot Genotypes. JAST, 19(2):365-376.

Son, L. (2018) Bazı Sofralık Kayısı Çeşitlerinin Silifke/Mersin Ekolojik Koşullarındaki Verim ve Kalite Özellikleri Üzerine Araştırmalar, Çukurova J. Agric. Food Sci. 33(2): 17-22.
Son, L., Bahar, A. (2018) Investigations on yield and quality characteristics of some early table apricot (Prunus armeniaca L.) cultivars in Manavgat (Antalya) ecological conditions. Mediterranean Agricultural Sciences, 31: 1-4.

Taha, N., Elsherif, H. (2015) Increasing Fruit Set, Yield and Fruit Quality of "Canino" Apricot Trees under Two Different Soil Conditions, British Journal of Applied Science \& Technology, 10(2): 1-18.

Uzun, A., Yaman, M., Pinar, H., Çetin, N., Say, A. (2018) Türkiye' de ekonomik olarak yetiştiriciliği yapılan sert çekirdekli meyvelerin üretim projeksiyonu. Bahçe, 47. 79-83.

Yanar, M. (2016) Bazı Kayısı Çeşit ve Genotiplerinin Fenolojik, Morfolojik, Pomolojik ve Moleküler Karakterizasyonu (Yayımlanmamış Yüksek Lisans Tezi). Mustafa Kemal Üniversitesi Fen Bilimleri Enstitüsü, Hatay.

Y1ld1z, E., Kaplankıran, M. (2017) The effect of cross-pollination on fruit set and quality in Robinson and Fremont mandarins, Ege Üniversitesi Ziraat Fakültesi, cilt.54, ss.107-112.

Yilmaz, K. U., Basbug, B., Gurcan, K., Pinar, H., Halasz, J., Ercisli, S., Cocen, E. (2016) SGenotype profiles of Turkish apricot germplasm. Notulae Botanicae Horti Agrobotanici Cluj-Napoca, 44(1), 67-71.

Yaman, M., \& Uzun, A. (2020) Evaluation of Superior Hybrid Individuals with Intra and Interspecific Hybridization Breeding in Apricot. International Journal of Fruit Science, 20(sup3), S2045-S2055.

Yaman, M., Uzun, A. (2021) Effects of Different Pollinators on Fruit Set and Quality Attributes of Texas Almond (Prunus dulcis L.) Cultivar. Horticultural Studies (HortiS), 38, 46-49.

Ortega, E., Egea, J., Dicenta, F. (2004) Effective pollination period in almond cultivars. Hortscience, 39, 19-22. 
Farklı Tozlayıcıların Precoce de Tyrinthe Kayısı Çeşidinin Bazı Meyve Özellikleri Üzerine Etkisi 